\title{
Reaction of common bean to Meloidogyne incognita race 1 and Meloidogyne javanica ${ }^{1}$
}

\author{
Cleiton Lourenço de Oliveira², Natália Souza Oliveira ${ }^{3 *}$, Márcia Souza de Oliveira ${ }^{3}$, Vicente Paulo Campos ${ }^{3}$, \\ Wilson Roberto Maluf ${ }^{3}$, Luiz Antônio Augusto Gomes ${ }^{3}$
}

$10.1590 / 0034-737 X 201865040004$

\begin{abstract}
Identification of common bean genotypes resistant to the root-knot nematodes may be useful for bean breeding programs. The objective of this study was to evaluate the reaction of bean genotypes to $M$. incognita race 1 and $M$. javanica. Two independent trials to assess resistance to both root-knot nematodes were carried out with fifty-eight common bean genotypes and six snap bean genotypes. The experiments were arranged in a randomized block design, with three replications and two plants per plot. A total of 10,000 nematode eggs were inoculated per plant 15 days after germination. At forty-five days after inoculation, the root system of each plant was harvested and the nematode eggs were extracted. The number of eggs per gram of root was counted and the Reproduction Factor and the Reduction of the Reproduction Factor were calculated. The performance of the genotypes differed between the trials, indicating different resistance reactions to the nematode species evaluated. The genotypes VP-25 and BRS Valente were resistant to $M$. incognita race 1. The genotypes Aporé, Ouro Vermelho, Radiante, and CNFP 10793 showed good resistance to both $M$. incognita race 1 and $M$. javanica, with potential as source of resistance in breeding programs. There was a significant correlation between root mass and number of eggs. The correlation between nematode reproduction and shoot mass was null.
\end{abstract}

Keywords: Phaseolus vulgaris; root-knot nematode; resistance.

\section{RESUMO}

\section{Reação de genótipos de feijão a Meloidogyne incognita raça 1 e a Meloidogyne javanica}

A identificação de genótipos de feijão resistentes aos nematoides das galhas pode ser útil aos programas de melhoramento do feijoeiro. Objetivou-se com este trabalho verificar a reação de genótipos de feijão aos nematoides das galhas $M$. incognita raça 1 e $M$. javanica. Dois ensaios independentes para avaliação da reação de resistência a Meloidogyne incognita raça 1 e Meloidogyne javanica foram realizados com cinquenta e oito genótipos de feijão e seis genótipos de feijão vagem. O delineamento foi em blocos casualizados com três repetições e parcelas de duas plantas. As plantas foram inoculadas com 10.000 ovos por planta aos quinze dias após a germinação. Aos quarenta e cinco dias após a inoculação, o sistema radicular de cada planta foi colhido e submetido à extração dos ovos. Foram obtidos dados de número de ovos por grama de raiz e calculados o fator de reprodução e a redução do fator de reprodução. $O$ comportamento dos genótipos divergiu entre os ensaios, indicando diferentes reações de resistência conforme a espécie de nematoide avaliada. Os genótipos VP-25 e BRS Valente foram considerados resistentes a M. incognita raça 1. Os genótipos Aporé, Ouro Vermelho, Radiante e CNFP 10793 apresentaram bons resultados de resistência tanto a $M$. incognita raça 1 quanto a $M$. javanica, podendo servir como fontes de resistência para programas de melhoramento. Houve correlação significativa entre massa de raiz e número de ovos. A correlação entre reprodução do nematoide e massa de parte aérea foi nula.

Palavras-chave: Phaseolus vulgaris; nematoide das galhas; resistência.

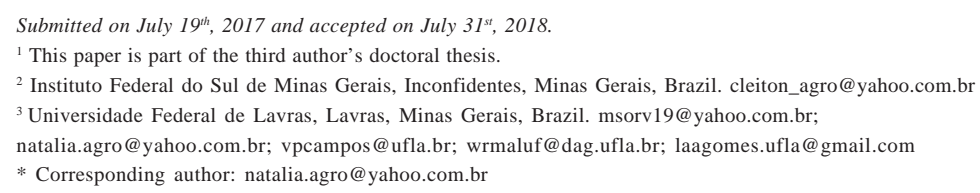




\section{INTRODUCTION}

Brazil is the world's largest producer and consumer of common bean (Phaseolus vulgaris L.). All social classes in Brazil consume beans, but is more important for the lowincome population, as it is the main dietary protein source (Souza et al., 2016).

In 2016, the estimated planted area of common bean in Brazil was 2.9 million hectares with production of 2.6 million tons, resulting in an average yield of less than one ton per hectare. The main producing states are Paraná with 23.3\%, Minas Gerais with $20.3 \%$, and Goiás with $13.4 \%$ of the national production (IBGE, 2017). Despite being the largest producer in terms of volume, Brazil has lower yields than the United States, China, and Argentina, with average yields of 1.94, 1.61, and 1.13 tons per hectare, respectively (FAO, 2013).

Among the reasons for this low productivity is occurrence of diseases, especially root-knot nematodes of the genus Meloidogyne. According to Baida et al. (2011), these pathogens can lead to bean yield drops of up to $90 \%$, with predominant occurrence in high-temperature regions (Pedrosa et al., 2000).

Some of the main symptoms of nematode attack to bean crops are uneven plant growth, wilting during the hottest part of the day, and dwarfism (Ferraz \& Monteiro, 1995). Other typical symptoms of nematodes affecting the physiological development of common bean are reduction in shoot and total mass of roots, smaller number of reproductive buds, pods, and seeds, with consequent drop in production (Baida et al., 2011).

Roots are damaged by the formation of giant cells, hyperplasia and hypertrophy of cells, leading to severe symptoms of nutritional deficiency in the shoot accompanied by a progressive decline of the plant (Ferraz \& Monteiro, 1995). Baida et al. (2011) showed that the average weight of roots can be significantly influenced in relation to controls non-inoculated with Meloidogyne spp., which respond to nematode attack, resulting in lower root weight.

Problems that hamper the development of the root system such as compacted soil layer, excess or lack of liming, and periods of water deficit can aggravate nematode parasitism symptoms (Almeida et al., 1997), compromising root development which is of crucial for the plant establishment and its productive capacity.

Resistance to Meloidogyne spp. has been reported in several herbaceous and woody plants, as well as annual and perennial crops in tropical and temperate regions (Cook \& Starr, 2006). In beans, control of the root-knot nematodes occurs mainly by cultural practices, as, for example, crop rotation. However, Charchar et al. (1995) pointed out that crop rotation may not be efficient when it comes to snap bean, which also belongs to the species $P$. vulgaris, but is consumed green as a vegetable. This plant is often grown after the tomato harvest, so that successive crops of root-knot nematode host plants in the same field can increase the nematode population density in a short time, resulting in early plant decline. The identification of bean genotypes with some degree of resistance has been frequently reported in the literature (Silva et al., 2005). Such genotypes become important as a source of resistance to be used in breeding programs, in both dry bean and snap bean.

The reproduction of gall-forming nematodes in common bean roots may indicate different degrees of resistance or tolerance between genotypes and, consequently, allow the separation of the most efficient genotypes for the reduction of population growth of Meloidogyne species (Simão et al., 2005). Silva \& Campos (2002) also suggest that there is a difference in parasitism among species or nematode isolates, so that a single bean genotype can react differently to the pathogen.

Cook \& Evans (1987) defined as completely resistant the plant that does not allow the reproduction of the nematodes and as non-resistant or susceptible the plant that allows the free multiplication of nematodes. The same authors described as tolerant the plant that present weak lesions even when strongly infected with nematodes and intolerant the plant that undergo a lot of damage under the same conditions. In this way, resistance and tolerance are characters independent of a host plant.

Simão et al. (2005), studying M. javanica, noticed that the bean cultivars Pérola and Iapar 81 were considered tolerant, because no reduction in the production of pods was observed even under the occurrence of nematode reproduction. Cultivar Aporé is one of the most resistant to $M$. incognita (Silva et al., 2005). The selection of lines within cultivar Aporé resulted in the cultivar Pérola, one of the most planted in Brazil, particularly under central pivot irrigation. Nematode resistance is probably one of the reasons for its success (Pereira et al., 2002).

Despite the importance of genetic improvement and the several studies aimed at bean resistance to root-knot nematodes, this approach is not widely used, giving rise to chemical control or even keeping stagnant yields at levels below what is considered ideal. Cook \& Starr (2006) suggested some possible reasons for the non-use of plant resistance to nematodes such as that some reports of resistance may not have been accurate; the resistance currently available is often linked to undesirable characteristics; and that the natural genetic resistance tends to be very specific for use in intensive agriculture. In addition, the durability of resistant cultivars may be limited. 
Another reason for the use of conventional nematode control methods in beans is that prolonged use of the same nematode resistant cultivar may induce changes in breeds within the nematode species, resulting in different breeds that lead to the breakdown of resistance (Williamson \& Roberts, 2009). Resistance sources need to be identified, measured, and quantified to produce new cultivars that can keep the population below the threshold of economic damage. In addition, these cultivars are used in plant breeding programs to increase the tolerance or resistance to the attack of these phytoparasites, allowing the cultivation of beans in infested areas (Baida et al., 2011). The objective of this study was to verify the reaction of common bean genotypes to the root-knot nematodes $M$. incognita race 1 and $M$. javanica.

\section{MATERIALAND METHODS}

Fifty-eight dry bean genotypes and six snap bean genotypes were evaluated for resistance to $M$. incognita race 1 and $M$. javanica in two trials separately for each nematode species. The two trials were conducted at the facilities of HortiAgro Sementes S/A, at the Development and Technology Transfer Center at UFLA, Palmital Farm, in the municipality of Ijaci, MG, Brazil. The resistance test to $M$. incognita race 1 was carried out between September and November 2011, and the resistance test to $M$. javanica between November 2012 and January 2013. The trials were arranged in the randomized blocks design with three repetitions and plots consisting of two pots with one plant each. Tomato plants of cultivar Santa Clara were also cultivated to test the inoculum viability.

Three bean seeds were sown in a three-liter plastic pot filled with substrate containing soil, sand, and cattle manure in the ratio $2: 1: 1$. After emergence, the pots were thinned to one seedling per pot. Fifteen days after sowing, the substrate was inoculated with the nematode eggs. The inoculums were obtained from tomato plants cv. Santa Clara, susceptible to Meloidogyne spp., grown in $10 \mathrm{dm}^{3}$ pots in a greenhouse.

The inoculum was prepared according to the methodology of Bonetti \& Ferraz (1981). The roots containing galls were cut into $0.5 \mathrm{~cm}$ length pieces and ground in a blender for 45 seconds in $0.5 \%$ sodium hypochlorite solution $(\mathrm{NaOCl})$. The suspension was poured over two stacked sieves with the 200-mesh (0.074 $\mathrm{mm})$ above the 500 -mesh $(0.028 \mathrm{~mm})$ with abundant tap water, always avoiding pouring water directly onto the material. The material caught on the 500-mesh sieve, consisting of an egg suspension and a small amount of substrate, was separated by centrifugal flotation at 2000 rpm for $5 \mathrm{~min}$ and at 1600 r.p.m. for $1 \mathrm{~min}$, in order to separate the eggs from the soil. The eggs were collected with a plastic squeeze bottle into glass beakers and then taken to the stereomicroscopic microscope for counting to calibrate the suspension in counting dishes containing $1 \mathrm{ml}$ aliquots.

For inoculation, we used a veterinary syringe to pour the solution with eggs about $1.5 \mathrm{~cm}$ from the stem of each plant. Five applications of $2 \mathrm{~mL}$ of suspension were made, each containing 2,000 eggs, totaling 10,000 eggs per plant.

Forty-five days after inoculation, the plants were removed from the pots for evaluation. The roots were washed in standing water to remove the substrate adhered to them. Afterwards, they were dried with paper towel, the mass of the root system and the mass of the aerial part were weighed in grams, the latter only for the experiment with $M$. javanica. The roots were cut with scissors in segments of $0.5 \mathrm{~cm}$ in length, and the eggs were extracted according to the Bonetti \& Ferraz (1981) technique. At the end, the eggs found in each root system were counted in a stereoscopic microscope, corresponding to the final nematode population. Next, the nematode population was quantified in eggs per gram of root and the reproduction factor $(\mathrm{RF})$ and the reproduction factor reduction (RFR) were calculated for classification of bean genotypes for nematode resistance (Table 1). RF was calculated by the ratio between the final number of eggs $(\mathrm{Pf})$ and the number of inoculated eggs $(\mathrm{Pi})$. RFR was obtained by the formula $R F R=\left(\frac{F R p-F R c}{F R p}\right) \times 100$, where FRp and FRc correspond to the RF of the standard susceptible cultivar (cv. Bolinha) and the cultivar evaluated, respectively.

Statistical analyses were performed using the Sisvar program (Ferreira, 2014), and the normality of errors associated with the plot was tested with the Shapiro-Wilk test at $5 \%$ probability. The data were submitted to the Ftest of the analysis of variance and the Scott-Knott (1974) multiple comparison test at $5 \%$ of error probability. Data on number of eggs per gram of root were $\operatorname{Ln}(X)$ transformed and on reproduction factor were $\sqrt{X}$ transformed. Finally, Pearson correlation (Table 2) was used to verify the relationships between the plant mass characteristics and nematode reproduction.

Table 1: Classification of plant reaction to nematode in relation to the reproduction factor reduction (RFR). Adapted from Moura \& Régis (1987)

\begin{tabular}{lcc}
\hline RFR & Classification & Abbreviation \\
\hline$\geq 100$ & Highly resistant or immune to & HR \\
$\leq 96<100$ & Resistant & R \\
$\leq 76<96$ & Little resistant & LR \\
$\leq 51<76$ & Moderately resistant & MR \\
$\leq 26<51$ & Susceptible & $\mathrm{S}$ \\
$<26$ & Highly susceptible & HS \\
\hline
\end{tabular}

Rev. Ceres, Viçosa, v. 65, n.4, p. 321-328, jul/ago, 2018 
Table 2: Pearson correlation coefficients between total number of eggs (TNE), number of eggs per gram of root (NEGR), reproduction factor (RF), reproductive factor reduction (RFR) of nematodes $M$. incognita race 1 and $M$. javanica, root mass (MR), and shoot mass (SM) of bean plants

\begin{tabular}{|c|c|c|c|c|c|c|c|c|c|}
\hline & \multicolumn{4}{|c|}{ M. incognita race 1} & \multicolumn{5}{|c|}{ M. javanica } \\
\hline & TNE & NEGR & $\mathbf{R F}$ & RFR & TNE & NEGR & $\mathbf{R F}$ & RFR & $\mathbf{S M}$ \\
\hline $\mathrm{RM}$ & $0,26 * *$ & $-0,12^{\text {n.s. }}$ & $0,26 * *$ & $-0,26^{* *}$ & $0,16^{*}$ & $0,004^{\text {n.s. }}$ & $0,16^{*}$ & $-0,16^{*}$ & $0,36 * *$ \\
\hline TNE & & $0,82 * *$ & $1,00 * *$ & $-1,00 * *$ & & $0,90 * *$ & $0,99 * *$ & $-0,99 * *$ & $0,05^{\text {n.s. }}$ \\
\hline NEGR & & & $0,82 * *$ & $-0,82 * *$ & & & $0,90 * *$ & $-0,90 * *$ & $-0,02^{\text {n.s. }}$ \\
\hline $\mathrm{RF}$ & & & & $-1,00 * *$ & & & & $-0,99 * *$ & $0,05^{\text {n.s. }}$ \\
\hline
\end{tabular}

*, ** Significant at 1 and $5 \%$, respectively, by the t-test.

n.s. = non-significant

Table 3: Root mass (RM), number of eggs per gram of roots (NEGR), reproduction factor (RF), reproduction factor reduction (RFR), and classification of the bean genotype reaction to the nematode Meloidogyne incognita race 1

\begin{tabular}{|c|c|c|c|c|c|}
\hline \multirow{2}{*}{ Genotype $^{1}$} & \multicolumn{5}{|c|}{ Meloidogyne incognita race 1} \\
\hline & RM & NEGR & $\mathbf{R F}$ & RFR & Reaction \\
\hline Aporé & $32,58 a^{*}$ & $2,88 \mathrm{a}$ & $0,23 \mathrm{a}$ & 98,95 & $\mathrm{R}$ \\
\hline Talismã & $81,5 \mathrm{~b}$ & $4,00 \mathrm{a}$ & $0,69 \mathrm{a}$ & 89,43 & LR \\
\hline VP-25 & $21,04 \mathrm{a}$ & 4,05 a & $0,35 \mathrm{a}$ & 97,67 & $\mathrm{R}$ \\
\hline VR 169 & $59,43 \mathrm{a}$ & $4,25 \mathrm{a}$ & $0,63 \mathrm{a}$ & 92,67 & LR \\
\hline BRS Valente & $21,06 \mathrm{a}$ & $4,47 \mathrm{a}$ & $0,45 \mathrm{a}$ & 96,19 & $\mathrm{R}$ \\
\hline BRS Esplendor & $42,44 \mathrm{a}$ & $4,48 \mathrm{a}$ & $0,70 \mathrm{a}$ & 89,35 & LR \\
\hline CNFP 11980 & $120,89 \mathrm{~b}$ & $4,51 \mathrm{a}$ & $1,16 \mathrm{a}$ & 72,07 & MR \\
\hline Macarrão Atibaia & $40,33 \mathrm{a}$ & $4,75 \mathrm{a}$ & $0,79 \mathrm{a}$ & 84,83 & LR \\
\hline CNFC-11965 & $31,93 \mathrm{a}$ & $4,78 \mathrm{a}$ & $0,60 \mathrm{a}$ & 93,67 & LR \\
\hline VCIII-2 & $28,5 \mathrm{a}$ & $4,81 \mathrm{a}$ & $0,57 \mathrm{a}$ & 94,11 & LR \\
\hline VC-17 & $42,09 \mathrm{a}$ & $4,85 \mathrm{a}$ & $0,78 \mathrm{a}$ & 86,50 & LR \\
\hline VC-18 & 24,66 a & $4,89 \mathrm{a}$ & $0,83 \mathrm{a}$ & 84,07 & LR \\
\hline Ouro Negro & $51,82 \mathrm{a}$ & $4,99 \mathrm{a}$ & $0,95 \mathrm{a}$ & 80,31 & LR \\
\hline RAD/E550-284 & $81,81 \mathrm{~b}$ & $5,01 \mathrm{a}$ & $1,09 \mathrm{a}$ & 79,40 & LR \\
\hline PT-68 & $19,75 \mathrm{a}$ & 5,09 a & $0,53 \mathrm{a}$ & 94,74 & LR \\
\hline CNFP 10793 & $23,01 \mathrm{a}$ & $5,12 \mathrm{a}$ & $0,61 \mathrm{a}$ & 93,36 & LR \\
\hline PT-65 & 35,65 a & $5,18 \mathrm{a}$ & $1,06 \mathrm{a}$ & 69,40 & MR \\
\hline VC-22 & $43,4 \mathrm{a}$ & $5,20 \mathrm{a}$ & $0,88 \mathrm{a}$ & 86,73 & LR \\
\hline VP-27 & $52,03 \mathrm{a}$ & $5,22 \mathrm{a}$ & $1,28 \mathrm{a}$ & 58,43 & MR \\
\hline VR-14 & 58,98 a & $5,27 \mathrm{a}$ & $1,08 \mathrm{a}$ & 79,34 & LR \\
\hline MAIV-18.254 & $89,65 \mathrm{~b}$ & $5,28 \mathrm{a}$ & $1,41 \mathrm{a}$ & 60,61 & MR \\
\hline CNFP 11990 & $31,11 \mathrm{a}$ & $5,30 \mathrm{a}$ & $0,82 \mathrm{a}$ & 87,26 & LR \\
\hline CNFC 15288 & $41,15 \mathrm{a}$ & $5,34 \mathrm{a}$ & $0,92 \mathrm{a}$ & 85,43 & LR \\
\hline Macarrão Trepador & 34,39 a & $5,36 \mathrm{a}$ & $0,90 \mathrm{a}$ & 84,53 & LR \\
\hline Ouro Vermelho & $46,41 \mathrm{a}$ & $5,40 \mathrm{a}$ & $1,02 \mathrm{a}$ & 80,95 & LR \\
\hline VP-28 & $44,23 \mathrm{a}$ & $5,40 \mathrm{a}$ & $1,00 \mathrm{a}$ & 81,85 & LR \\
\hline CVIII-5 & 54,09 a & $5,41 \mathrm{a}$ & $1,32 \mathrm{a}$ & 54,29 & MR \\
\hline BRS Timbó & 34,13 a & $5,42 \mathrm{a}$ & $0,90 \mathrm{a}$ & 85,37 & LR \\
\hline VP-26 & $66,88 \mathrm{~b}$ & $5,50 \mathrm{a}$ & $1,03 \mathrm{a}$ & 81,42 & LR \\
\hline VR-158 & $37,32 \mathrm{a}$ & $5,51 \mathrm{a}$ & $1,04 \mathrm{a}$ & 78,68 & LR \\
\hline Macarrão Favorito & 32,7 a & $5,52 \mathrm{a}$ & $0,91 \mathrm{a}$ & 84,85 & LR \\
\hline $\mathrm{VP}-24$ & $51,33 \mathrm{a}$ & $5,61 \mathrm{a}$ & $1,18 \mathrm{a}$ & 75,24 & LR \\
\hline Radiante & $17,62 \mathrm{a}$ & $5,64 \mathrm{a}$ & $0,83 \mathrm{a}$ & 83.94 & LR \\
\hline Mac. Rasteiro Conquista & a $35,01 \mathrm{a}$ & 5,65 a & $0,98 \mathrm{a}$ & 83,45 & LR \\
\hline RCII-2.19 & 54,01 a & $5,68 \mathrm{a}$ & $1,32 \mathrm{a}$ & 66,19 & MR \\
\hline CNFC 10408 & $49,89 \mathrm{a}$ & $5,77 \mathrm{a}$ & $1,42 \mathrm{a}$ & 56,32 & MR \\
\hline MAIV-18.259 & $96,65 \mathrm{~b}$ & $5,79 \mathrm{a}$ & $1,78 \mathrm{a}$ & 45,59 & MR \\
\hline
\end{tabular}


Continuation of table 3

\begin{tabular}{|c|c|c|c|c|c|}
\hline \multirow[t]{2}{*}{ Genotype $^{1}$} & \multicolumn{5}{|c|}{ Meloidogyne incognita race 1} \\
\hline & $\mathbf{R M}$ & NEGR & RF & RFR & Reaction \\
\hline Macarrão Preferido & $28,57 \mathrm{a}$ & $5,80 \mathrm{a}$ & $0,91 \mathrm{a}$ & 85,43 & PR \\
\hline VP-29 & $47,1 \mathrm{a}$ & $5,81 \mathrm{a}$ & $1,22 \mathrm{a}$ & 74,26 & MR \\
\hline CNFC-10432 & $23,35 \mathrm{a}$ & $5,85 \mathrm{a}$ & $0,93 \mathrm{a}$ & 83,58 & LR \\
\hline VC-21 & $50,81 \mathrm{a}$ & $5,85 \mathrm{a}$ & $1,34 \mathrm{a}$ & 67,23 & MR \\
\hline Macarrão Rasteiro & $60,39 \mathrm{a}$ & $5,86 \mathrm{a}$ & $1,62 \mathrm{a}$ & 43,31 & S \\
\hline VP-18.163 & $73,34 \mathrm{~b}$ & $5,87 \mathrm{a}$ & $1,60 \mathrm{a}$ & 55,20 & MR \\
\hline VC-20 & $34,53 \mathrm{a}$ & $5,90 \mathrm{a}$ & $1,25 \mathrm{a}$ & 67,26 & MR \\
\hline Jalo EEP12 & $40,65 \mathrm{a}$ & $5,90 \mathrm{a}$ & $1,23 \mathrm{a}$ & 71,69 & MR \\
\hline VR-18 & $32,43 \mathrm{a}$ & $5,92 \mathrm{a}$ & $1,09 \mathrm{a}$ & 78,35 & LR \\
\hline VR-17 & $28,3 \mathrm{a}$ & $5,94 \mathrm{a}$ & $1,30 \mathrm{a}$ & 59,27 & MR \\
\hline EMB-4 & 39,67 a & $5,95 \mathrm{a}$ & $1,21 \mathrm{a}$ & 73,57 & MR \\
\hline CNFP 11992 & $35,15 \mathrm{a}$ & $5,96 \mathrm{a}$ & $1,34 \mathrm{a}$ & 59,37 & MR \\
\hline VC-19 & $44,34 \mathrm{a}$ & $6,00 \mathrm{a}$ & $1,43 \mathrm{a}$ & 60,46 & MR \\
\hline Pérola & $47,83 \mathrm{a}$ & $6,00 \mathrm{a}$ & $1,40 \mathrm{a}$ & 61,54 & MR \\
\hline CNFP 11977 & $33,26 \mathrm{a}$ & $6,02 \mathrm{a}$ & $1,26 \mathrm{a}$ & 67,37 & MR \\
\hline CNFC 10763 & $42,99 \mathrm{a}$ & $6,02 \mathrm{a}$ & $1,46 \mathrm{a}$ & 53,55 & MR \\
\hline BRS Vereda & $37,32 \mathrm{a}$ & 6,06 a & $1,25 \mathrm{a}$ & 72,09 & MR \\
\hline RC2 RAD-155 & $38,57 \mathrm{a}$ & $6,10 \mathrm{a}$ & $1,33 \mathrm{a}$ & 68,23 & MR \\
\hline CNFR x 152754 & $50,84 \mathrm{a}$ & $6,12 \mathrm{a}$ & $1,57 \mathrm{a}$ & 54,30 & MR \\
\hline $\mathrm{VC}-3$ & $22,78 \mathrm{a}$ & $6,28 \mathrm{a}$ & $1,16 \mathrm{a}$ & 73,91 & MR \\
\hline EMB-14 & $28,83 \mathrm{a}$ & $6,30 \mathrm{a}$ & $1,38 \mathrm{a}$ & 58,05 & MR \\
\hline BRS Campeiro & $47,03 \mathrm{a}$ & $6,32 \mathrm{a}$ & $1,62 \mathrm{a}$ & 53,22 & MR \\
\hline VC-23 & $46,12 \mathrm{a}$ & $6,38 \mathrm{a}$ & $1,69 \mathrm{a}$ & 44,49 & $\mathrm{~S}$ \\
\hline CNFP 10103 & $37,8 \mathrm{a}$ & $6,41 \mathrm{a}$ & $1,45 \mathrm{a}$ & 63,44 & MR \\
\hline MAIV-15.204 & 56,29 a & $6,45 \mathrm{a}$ & $1,90 \mathrm{a}$ & 35,61 & $\mathrm{~S}$ \\
\hline Bolinha & $33,98 \mathrm{a}$ & $6,87 \mathrm{a}$ & $2,13 \mathrm{a}$ & Standard & Standard \\
\hline EMB-9 & $37,39 \mathrm{a}$ & $6,96 \mathrm{a}$ & $1,93 \mathrm{a}$ & 35,57 & S \\
\hline
\end{tabular}

* Means followed by the same letter in the column are not significant different by Scott-Knott's (1974) test at 5\% probability; ${ }^{1}$ Genotypes in bold are snap beans.

\section{RESULTS AND DISCUSSION}

The classification of bean cultivars for nematode resistance are shown in Tables 3 and 4 . The results of number of eggs per gram of root of tomato plants in both trials confirm the viability of the inocula. No cultivar was classified as highly resistant or immune. In both trials, cv. Aporé was classified as resistant. This result is consistent and corroborates the findings from the study by Ferreira et al. (2010), in which, although using another grading scale, cv. Aporé was classified as slightly resistant to $M$. incognita race 1 and highly resistant to $M$. javanica.

The genotypes VP-25 and BRS-Valente were classified as resistant to $M$. incognita race 1 , but highly susceptible to $M$. javanica. A possible explanation for this difference in resistance to different nematode species can be given by analyzing the RFR values, which are too small in the $M$. javanica trial, probably due to the high temperatures during the experiment, which may have influenced the reduction in root mass, leading to the loss of two treatments: cultivars Macarrão Rasteiro and Macarrão Rasteiro Conquista. Thus, when observing the behavior of the susceptible standard cultivar Bolinha, with root mass of 33.98 grams in the trial with $M$. incognita race 1 and 2.78 grams in the trial with $M$. javanica, one can consider that this reduction led to a drop in the total number of eggs, which in turn increased the reproduction factor resulting in the low RFR values found for VP-25 and BRS Valente. This same reduction was also observed in the tomato cultivar Santa Clara, with root mass of 61.41 grams in the trial with $M$. incognita race 1 and 22.66 grams in the trial with $M$. javanica.

The same explanation can also be given for the drop in the resistance classification of the snap bean genotypes (in bold in Tables 3 and 4). In the trial with $M$. incognita race 1 , the resistance classifications were consistent with those found by Ferreira et al. (2010), who separated bean genotypes in moderately resistant, resistant, and susceptible to $M$. incognita race 1 . However, in the trial with $M$. javanica, there were drops for all genotypes evaluated, including genotypes classified as highly susceptible, which did not occur in the $M$. incognita race 1 trial for any of the genotypes evaluated. Even in the face 
Table 4: Shoot mass (SM), root mass (RM), number of eggs per gram of roots (NEGR), reproduction factor (RF), reproduction factor reduction (RFR), and bean genotype reaction to nematode Meloidogyne javanica

\begin{tabular}{|c|c|c|c|c|c|c|}
\hline \multirow{2}{*}{ Genotype $^{1}$} & \multirow[b]{2}{*}{$\mathbf{S M}$} & \multicolumn{5}{|c|}{ Meloidogyne javanica } \\
\hline & & $\mathbf{R M}$ & NEGR & $\mathbf{R F}$ & RFR & Reaction \\
\hline CNFP 10793 & $3,64 a^{*}$ & $14,14 \mathrm{a}$ & $2,44 \mathrm{a}$ & $0,12 \mathrm{a}$ & 91,08 & LR \\
\hline VP-18.163 & 5,97 a & $12,26 \mathrm{a}$ & $3,02 \mathrm{a}$ & $0,16 \mathrm{a}$ & 84,84 & LR \\
\hline Aporé & $4,60 \mathrm{a}$ & $2,63 \mathrm{a}$ & $3,04 \mathrm{a}$ & $0,06 \mathrm{a}$ & 97,31 & $\mathrm{R}$ \\
\hline CNFP 11992 & $2,86 \mathrm{a}$ & $22,61 \mathrm{a}$ & $3,46 \mathrm{a}$ & $0,13 \mathrm{a}$ & 85,43 & LR \\
\hline Talismã & $12,42 \mathrm{c}$ & $13,04 \mathrm{a}$ & $3,60 \mathrm{a}$ & $0,25 \mathrm{a}$ & 53,53 & MR \\
\hline VC-17 & $3,55 \mathrm{a}$ & $13,03 \mathrm{a}$ & $3,62 \mathrm{a}$ & $0,21 \mathrm{a}$ & 73,85 & MR \\
\hline BRS Campeiro & $2,79 \mathrm{a}$ & $7,68 \mathrm{a}$ & $3,67 \mathrm{a}$ & $0,15 \mathrm{a}$ & 87,20 & LR \\
\hline Ouro Vermelho & $7,97 \mathrm{~b}$ & $9,88 \mathrm{a}$ & $3,70 \mathrm{a}$ & $0,18 \mathrm{a}$ & 78,98 & $\mathrm{LR}$ \\
\hline PT-68 & $4,60 \mathrm{a}$ & 8,16 a & $3,81 \mathrm{a}$ & $0,20 \mathrm{a}$ & 70,09 & MR \\
\hline EMB-14 & $4,01 \mathrm{a}$ & $7,15 \mathrm{a}$ & $3,81 \mathrm{a}$ & $0,21 \mathrm{a}$ & 62,09 & MR \\
\hline VR-17 & $8,35 \mathrm{~b}$ & $9,17 \mathrm{a}$ & $3,95 \mathrm{a}$ & $0,19 \mathrm{a}$ & 76,91 & LR \\
\hline EMB-9 & $9,48 \mathrm{~b}$ & $12,46 \mathrm{a}$ & $4,06 \mathrm{a}$ & $0,40 \mathrm{a}$ & $-75,92$ & HS \\
\hline CNFP 11977 & $5,95 \mathrm{a}$ & 7,69 a & $4,06 \mathrm{a}$ & $0,22 \mathrm{a}$ & 67,22 & MR \\
\hline MAIV-15.204 & $7,16 \mathrm{~b}$ & $11,69 \mathrm{a}$ & $4,07 \mathrm{a}$ & $0,26 \mathrm{a}$ & 61,61 & MR \\
\hline $\mathrm{VC}-3$ & $3,60 \mathrm{a}$ & $6,45 \mathrm{a}$ & $4,12 \mathrm{a}$ & $0,20 \mathrm{a}$ & 75,88 & LR \\
\hline BRS Vereda & $4,06 \mathrm{a}$ & $4,94 \mathrm{a}$ & $4,12 \mathrm{a}$ & $0,18 \mathrm{a}$ & 79,35 & LR \\
\hline Macarrão Trepador & $5,91 \mathrm{a}$ & $11,54 \mathrm{a}$ & $4,13 \mathrm{a}$ & $0,34 \mathrm{a}$ & $-10,27$ & HS \\
\hline Radiante & $5,30 \mathrm{a}$ & $6,26 \mathrm{a}$ & $4,14 \mathrm{a}$ & $0,20 \mathrm{a}$ & 78,02 & LR \\
\hline VR-158 & $3,89 \mathrm{a}$ & $8,17 \mathrm{a}$ & $4,14 \mathrm{a}$ & $0,23 \mathrm{a}$ & 67,21 & MR \\
\hline VCIII-2 & $4,86 \mathrm{a}$ & $4,39 \mathrm{a}$ & $4,20 \mathrm{a}$ & $0,20 \mathrm{a}$ & 68,24 & MR \\
\hline VR-18 & $7,80 \mathrm{~b}$ & $5,91 \mathrm{a}$ & $4,28 \mathrm{a}$ & $0,22 \mathrm{a}$ & 65,04 & MR \\
\hline MAIV-18.259 & $5,88 \mathrm{a}$ & $11,83 \mathrm{a}$ & $4,30 \mathrm{a}$ & $0,34 \mathrm{a}$ & 8,10 & HS \\
\hline VC-20 & $4,09 \mathrm{a}$ & $7,41 \mathrm{a}$ & $4,51 \mathrm{a}$ & $0,30 \mathrm{a}$ & 39,66 & $\mathrm{~S}$ \\
\hline VC-21 & $8,70 \mathrm{~b}$ & $8,30 \mathrm{a}$ & $4,43 \mathrm{a}$ & $0,26 \mathrm{a}$ & 61,87 & MR \\
\hline VP-27 & $1,86 \mathrm{a}$ & $4,67 \mathrm{a}$ & $4,50 \mathrm{a}$ & $0,19 \mathrm{a}$ & 76,03 & LR \\
\hline BRS Valente & $5,93 \mathrm{a}$ & $29,28 \mathrm{a}$ & $4,51 \mathrm{a}$ & $0,45 \mathrm{a}$ & $-67,10$ & HS \\
\hline VP-26 & $3,40 \mathrm{a}$ & $7,14 \mathrm{a}$ & $4,53 \mathrm{a}$ & $0,25 \mathrm{a}$ & 64,08 & MR \\
\hline RC2 RAD-155 & $2,86 \mathrm{a}$ & $6,26 \mathrm{a}$ & $4,53 \mathrm{a}$ & $0,33 \mathrm{a}$ & 44,68 & $\mathrm{~S}$ \\
\hline VC-23 & $6,76 b$ & $8,29 \mathrm{a}$ & $4,60 \mathrm{a}$ & $0,33 \mathrm{a}$ & 17,57 & HS \\
\hline Macarrão Atibaia & $9,80 \mathrm{c}$ & $16,65 \mathrm{a}$ & $4,61 \mathrm{a}$ & $0,69 \mathrm{a}$ & $-165,65$ & HS \\
\hline CNFP 11990 & $3,15 \mathrm{a}$ & $3,81 \mathrm{a}$ & $4,64 \mathrm{a}$ & $0,21 \mathrm{a}$ & 71,68 & MR \\
\hline Ouro Negro & $3,75 \mathrm{a}$ & $4,96 \mathrm{a}$ & $4,67 \mathrm{a}$ & $0,21 \mathrm{a}$ & 73,67 & MR \\
\hline MAIV-18.524 & $5,90 \mathrm{a}$ & 18,66 a & $4,75 \mathrm{a}$ & $0,47 \mathrm{a}$ & $-53,35$ & HS \\
\hline VP-29 & $6,66 \mathrm{~b}$ & $6,48 \mathrm{a}$ & $4,78 \mathrm{a}$ & $0,27 \mathrm{a}$ & 54,60 & MR \\
\hline CNFP 10103 & $6,31 \mathrm{~b}$ & $6,75 \mathrm{a}$ & $4,84 \mathrm{a}$ & $0,28 \mathrm{a}$ & 54,42 & MR \\
\hline VP-24 & $8,31 \mathrm{~b}$ & $11,20 \mathrm{a}$ & $4,89 \mathrm{a}$ & $0,46 \mathrm{a}$ & $-16,98$ & HS \\
\hline Macarrão Preferido & $2,24 \mathrm{a}$ & $4,88 \mathrm{a}$ & $4,91 \mathrm{a}$ & $0,25 \mathrm{a}$ & 58,58 & MR \\
\hline CNFC 10763 & $7,32 \mathrm{~b}$ & 6,15 a & $4,93 \mathrm{a}$ & $0,29 \mathrm{a}$ & 49,03 & $\mathrm{~S}$ \\
\hline CNFC 15288 & $4,52 \mathrm{a}$ & $5,66 \mathrm{a}$ & $4,99 \mathrm{a}$ & $0,27 \mathrm{a}$ & 57,07 & MR \\
\hline RCII2.19 & $1,22 \mathrm{a}$ & $6,39 a$ & $5,05 \mathrm{a}$ & $0,28 \mathrm{a}$ & 55,41 & MR \\
\hline CNFC 11965 & $14,98 \mathrm{c}$ & 20,66 a & $5,09 \mathrm{a}$ & $0,67 \mathrm{a}$ & $-253,97$ & HS \\
\hline CNFR x 152754 & $1,63 \mathrm{a}$ & $2,88 \mathrm{a}$ & $5,10 \mathrm{a}$ & $0,21 \mathrm{a}$ & 73,63 & MR \\
\hline CNFC 10408 & $11,08 \mathrm{c}$ & 17,79 a & $5,20 \mathrm{a}$ & $0,70 \mathrm{a}$ & $-330,83$ & HS \\
\hline CNFC 10432 & 5,13 a & $11,09 \mathrm{a}$ & $5,23 \mathrm{a}$ & $0,44 \mathrm{a}$ & $-11,60$ & HS \\
\hline VR 169 & $10,17 \mathrm{a}$ & $13,38 \mathrm{a}$ & $5,24 \mathrm{a}$ & $0,53 \mathrm{a}$ & $-88,09$ & HS \\
\hline BRS Timbó & $3,71 \mathrm{a}$ & $6,90 \mathrm{a}$ & $5,25 \mathrm{a}$ & $0,33 \mathrm{a}$ & 35,17 & $\mathrm{~S}$ \\
\hline CNFP 11980 & $2,83 \mathrm{a}$ & $5,61 \mathrm{a}$ & $5,30 \mathrm{a}$ & $0,29 \mathrm{a}$ & 49,14 & $\mathrm{~S}$ \\
\hline RAD/E550-284 & $8,01 \mathrm{~b}$ & $7,33 \mathrm{a}$ & $5,32 \mathrm{a}$ & $0,57 \mathrm{a}$ & $-241,91$ & HS \\
\hline VP-25 & $6,99 \mathrm{~b}$ & $8,57 \mathrm{a}$ & $5,37 \mathrm{a}$ & $0,38 \mathrm{a}$ & 16,25 & HS \\
\hline Macarrão Favorito & $3,68 \mathrm{a}$ & $15,98 \mathrm{a}$ & $5,39 \mathrm{a}$ & $0,74 \mathrm{a}$ & $-212,59$ & HS \\
\hline VC-18 & $1,92 \mathrm{a}$ & $5,50 \mathrm{a}$ & $5,45 \mathrm{a}$ & $0,39 \mathrm{a}$ & 2,27 & HS \\
\hline
\end{tabular}


Continuation of table 4

\begin{tabular}{lcccccc}
\hline Genotype $^{1}$ & \multicolumn{7}{c}{ Meloidogyne javanica } \\
\cline { 2 - 7 } & SM & RM & NEGR & RF & RFR & Reaction \\
\hline CVIII-5 & $1,58 \mathrm{a}$ & $6,71 \mathrm{a}$ & $5,59 \mathrm{a}$ & $0,33 \mathrm{a}$ & 25,17 & HS \\
Bolinha & $2,26 \mathrm{a}$ & $2,78 \mathrm{a}$ & $5,60 \mathrm{a}$ & $0,34 \mathrm{a}$ & Standard & Standard \\
Pérola & $4,79 \mathrm{a}$ & $11,78 \mathrm{a}$ & $5,68 \mathrm{a}$ & $0,58 \mathrm{a}$ & $-137,62$ & HS \\
PT-65 & $4,03 \mathrm{a}$ & $6,73 \mathrm{a}$ & $5,85 \mathrm{a}$ & $0,62 \mathrm{a}$ & $-185,64$ & HS \\
BRS Esplendor & $2,41 \mathrm{a}$ & $4,29 \mathrm{a}$ & $5,87 \mathrm{a}$ & $0,38 \mathrm{a}$ & 13,70 & HS \\
EMB-4 & $5,26 \mathrm{a}$ & $15,45 \mathrm{a}$ & $5,88 \mathrm{a}$ & $0,61 \mathrm{a}$ & $-159,78$ & HS \\
VC-22 & $3,03 \mathrm{a}$ & $6,50 \mathrm{a}$ & $5,96 \mathrm{a}$ & $0,66 \mathrm{a}$ & $-297,79$ & HS \\
VR-14 & $6,47 \mathrm{~b}$ & $11,7 \mathrm{a}$ & $6,07 \mathrm{a}$ & $0,76 \mathrm{a}$ & $-315,90$ & HS \\
VC-19 & $2,47 \mathrm{a}$ & $4,80 \mathrm{a}$ & $6,23 \mathrm{a}$ & $0,59 \mathrm{a}$ & $-186,08$ & $\mathrm{HS}$ \\
VP-28 & $4,84 \mathrm{a}$ & $13,3 \mathrm{a}$ & $6,49 \mathrm{a}$ & $0,98 \mathrm{a}$ & $-566,35$ & HS \\
Jalo EPP12 & $5,37 \mathrm{a}$ & $8,86 \mathrm{a}$ & $6,94 \mathrm{a}$ & $1,67 \mathrm{a}$ & $-3163,88$ & HS \\
\hline
\end{tabular}

* * Means followed by the same letter in the column are not significant different by Scott-Knott's (1974) test at 5\% probability; ${ }^{1}$ Genotypes in bold are snap beans.

of these root mass reductions, some genotypes behaved as more resistant to $M$. javanica than to $M$. incognita, such as VP-18,163, CNFP 11992, BRS Campeiro, BRS Vereda, Radiante, VR-17, VC-3, and VP-27, which were moderately resistant to $M$. incognita race 1 and little resistant to $M$. javanica. The best performance of these genotypes in the $M$. javanica trial, even under the high temperatures reported above, suggests that sources of resistance to this species may be possible. In addition to the resistant cv. Aporé, acceptable levels of resistance to both nematodes were verified only for the genotypes CNFP 10793, Ouro Vermelho, and Radiante, which were little resistant in both trials.

Cultivar Pérola derives from a selection of lines from the resistant cv. Aporé and was classified as moderately resistant to $M$. incognita race 1 and highly susceptible to $M$. javanica. These results are similar to the study by Simão et al. (2005), who detected, despite the high reproductive factors, that this cultivar has a good tolerance to the nematode, allowing its reproduction under the minimum inoculum pressure without, however, affecting the production of pods. In the present study, no production data were collected, but the mean root mass of cv. Pérola was statistically equal to that of the resistant cv. Aporé in both trials, as well as the shoot mass in the $M$. javanica trial. Concurrently, cv. Pérola would also be classified as susceptible to $M$. incognita when using the BF-based classification. However, based on the criteria used by Moura \& Régis (1987), which better classify the behavior of the genotypes using the parasitological aspects that take into account RFR values and provide a wider classification for resistance, cv. Pérola was classified as moderately resistant.

Wesemael \& Moens (2012), working with bean resistance to $M$. chitwoodi, found results similar to those of cv. Pérola when they evaluated the resistance of cv. Polder. The authors observed that the nematode can penetrate the roots, but is not able to reproduce itself leading to a drop of the nematode population in the soil. They verified that yield was not affected by the high initial nematode concentration in the soil. Thus, the same mechanism of resistance may be involved with cv. Aporé, not allowing a good reproduction of the nematode in the two trials, considering the low BF values: 0.23 for $M$. incognita and 0.06 for M. javanica. Although the production data have not been evaluated, it is possible to infer that the ability of cv. Aporé to inhibit nematode reproduction is not affected, as is the case of cv. Polder used by these authors.

From the foregoing, it is possible that for some genotypes there is no relationship between plant productivity and resistance, so that both nematode tolerant and intolerant genotypes can occur with similar yields. The correlations presented in Table 2 reinforce this hypothesis. Low but significant values were detected between root mass and number of eggs, RF, and RFR in the two trials, indicating that the more roots, the greater the number of eggs. There was no significant correlation between number of eggs and shoot mass for M. javanica, reinforcing the possibility of good pod and seed yield, even under high nematode reproduction rates for some genotypes. Some cultivars had high shoot mass and low nematode reproduction, such as the cultivars Talismã, Ouro Vermelho, VR-17, and VP-29 (Table 4). Other cultivars, on the other hand, showed low shoot mass and high nematode reproduction, such as cultivars Jalo EPP 12 and BRS Esplendor. This divergence between shoot mass and nematode reproduction leads to the idea of a nonrelationship of these characteristics, making it possible genotypes with good yields even under high nematode reproduction, such as the cultivars Pérola (Simão et al., 2005) and Polder (Wesemael \& Moens, 2012) depending, of course, on the nematode species. 


\section{CONCLUSIONS}

There was difference in genotype resistance in each of the trials. For $M$. incognita race 1, the genotypes Aporé, VP-25, and BRS Valente were considered resistant, whereas for M. javanica, only Aporé was resistant;

The genotypes Ouro Vermelho, Radiante, and CNFP 10793 showed good resistance to both $M$. incognita race 1 and $M$. javanica, and together with cv. Aporé, they can serve as sources of resistance to these nematode species;

The correlation between nematode reproduction and shoot mass was null.

\section{ACKNOWLEDGEMENTS}

The authors thank the Coordenação de Aperfeiçoamento de Pessoal de Nivel Superior - CAPES, the Conselho Nacional de Desenvolvimento Científico $e$ Tecnológico - CNPq, and the Fundação de Amparo à Pesquisa do Estado de Minas Gerais - FAPEMIG for the financial support. They also thank HortiAgro Sementes $L t d a$. for providing facilities and materials used in the trials and the Laboratório de Nematologia of UFLA for lending the necessary equipment for the extraction and quantification of the nematode eggs.

\section{REFERENCES}

Almeida AMR, Ferreira LP, Yorinori J, Silva JFV \& Henning AA (1997) Doenças da soja. In: Kimati H, Amorin L, Bergamin A, Aranha LEA \& Rezende JAM (Eds.) Manual de fitopatologia: doenças de plantas cultivadas. São Paulo, Agronômica Ceres. p.596-617.

Baida FC, Santiago DC, Takahashi LSA, Athanázio JC, Cadioli MC \& Levy RM (2011) Reação de linhagens de feijão vagem ao Meloidogyne javanica e $M$. paranaensis em casa-de-vegetação. Acta Scientiarum. Agronomy, 33:237-241.

Bonetti JIS \& Ferraz S (1981) Modificação do método de Hussey \& Barker para extração de ovos de Meloidogyne exigua de raízes de cafeeiro. Fitopatologia Brasileira, 6:553.

Charchar JM (1995) Meloidogyne em hortaliças. In: $19^{\circ}$ Congresso Internacional de Nematologia Tropical / Congresso da Sociedade Brasileira de Nematologia / $27^{\circ}$ Encontro Anual da Organização dos Nematologistas da América Tropical, Rio Quente. Anais, SBN/ONTA. p.149-153.

Cook R \& Evans K (1987) Resistance and tolerance. In: Brown RH \& Kerry BR (Eds.) Principles and Practice of Nematode Control in Crops. London, Academic Press. p. 179-231.

Cook R \& Starr JL (2006) Resistant cultivars. In: Perry RN \& Moens M (Eds.) Plant Nematology. Wallingford, CABI. p. 370391 .

FAO - Food and Agriculture Organization of the United Nations. Crops. Disponível em: <http://faostat.fao.org/site/567/ DesktopDefault.aspx?PageID=567\#ancor $>$ Acessado em: $08 \mathrm{de}$ julho de 2013.

Ferraz CCB \& Monteiro AR (1995) Nematoides. In: Bergamin Filho A, Kimati H \& Amorim L (Eds.) Manual de fitopatologia: princípios e conceitos. $3^{\mathrm{a}}$ ed. São Paulo, Agronômica Ceres. p. 168-201.

Rev. Ceres, Viçosa, v. 65, n.4, p. 321-328, jul/ago, 2018
Ferreira DF (2014) Sisvar: a guide for its Bootstrap procedures in multiple comparisons. Ciência e Agrotecnologia, 38:109-112.

Ferreira S, Gomes LAA, Maluf WR, Campos VP, Carvalho Filho JLS \& Santos DC (2010) Resistance of dry bean and snap bean cultivars to root-knot nematodes. HortScience, 45:320-322.

IBGE - Instituto Brasileiro de Geografia e Estatística (2017) Indicadores IBGE. Disponível em: <htp://ftp.ibge.gov.br/ Producao_Agricola/Fasciculo_Indicadores_IBGE/ estProdAgr_201701.pdf>. Acessado em: 17 de julho de 2017.

Moura RM \& Regis EMO (1987) Reações de feijoeiro comum (Phaseolus vulgaris) em relação ao parasitismo de Meloidogyne javanica e $M$. incognita (Nematoda: Heteroderidae). Nematologia Brasileira, 10:215-225.

Pedrosa EMR, Moura RM \& Silva EG (2000) Respostas de genótipos de Phaseolus vulgaris a meloidoginoses e alguns mecanismos envolvidos na reação. Fitopatologia Brasileira, 25:190196.

Pereira JM, Vieira RF \& Marrara LO (2002) Reação de cultivares e linhagens de feijão à murcha-de-fusarium. Revista Ceres, 49:7174.

Scott A \& Knott M (1974) Cluster-analysis method for grouping means in analysis of variance. Biometrics, 30:507-512.

Silva JV \& Campos HD (2002) Reação de cultivares de feijão a nematoides de galhas. In: $7^{\circ}$ Congresso Nacional de Pesquisa de Feijão, Viçosa. Resumos expandidos, Universidade Federal de Viçosa. p.102.

Silva FB, Ramalho MAP \& Abreu AFB (2005) Genetic control of Meloidogyne incognita resistance in common bean. Annual Report of the Bean Improvement Cooperative, 48:64-65.

Simão G, Homechin M, Santiago DC, Silva RTV \& Ribeiro ER (2005) Comportamento de duas cultivares de feijoeiro em relação a Meloidogyne javanica. Ciência Rural, 35:266-270.

Souza RS, Wander AE, Cunha CA \& Scalco PR (2016) Ajustamento assimétrico de preços na cadeia produtiva do feijão no Estado de Goiás, Brasil. Agroalimentaria, 22:133-148.

Wesemael WML \& Moens AM (2012) Screening of common bean (Phaseolus vulgaris) for resistance against temperate rootknot nematodes (Meloidogyne spp.). Pest Management Science, 68:702-708.

Williamson VM \& Roberts PA (2009) Mechanisms and genetics of resistance. In: Perry RN, Moens M \& Starr JL (Eds.) Rootknot Nematodes. Wallingford, CABI. p. 301-325. 